\title{
Between the ethics of forgiveness and the unforgivable: Reflections on Arendt's idea of reconciliation in politics*
}

\author{
Rafał WONICKI**
}

\begin{abstract}
The aim of the article is to examine the role that memory and oblivion, forgiveness and unforgiveness play in Hannah Arendt's thought in relation to acts of violence in the political sphere. Political communities do not always decide to remember the crimes they have committed or the wrongs they have suffered, but neither can they always forget their mutual harms, even when there is already peace between them. Without striving to exhaust the entire subject matter of Arendt's work, I would like to illustrate the difficulty of understanding the role forgiveness plays in her thought as well as to indicate possible solutions when forgiveness becomes unachievable within the framework of her considerations. Her reflection can be divided into two stages. The first is a focus on the idea of radical evil and the need to forgive perpetrators for their crimes. Second, under the influence of the Adolf Eichmann trial, she developed the idea of the banality of evil. This idea points to situations so terrible that they transcend all human moral judgment, making forgiveness impossible. However, even when the moral possibility of individual forgiveness has been rejected, when the legal possibility of seeking justice has been exhausted and when victims and perpetrators in the community are still unable to live together peacefully, Arendt's thought leads us to the possibility of political reconciliation.
\end{abstract}

\section{KEYWORDS}

coercion; Adolf Eichmann; crime; evil; perpetrators; political oblivion; amnesty

* I would like to thank the two anonymous reviewers for their comments and suggestions. I wanted to thank also to Prof. Piotr Nowak and dr Magdalena Gawin for the discussion on the first version of the text during the conference called "Collective memory and collective oblivion" (20-21.09.2019, Warsaw).

** Ph.D. (habil.), Institute of Philosophy, University of Warsaw, Poland. E-mail: rafalwonicki @uw.edu.pl. 
The aim of this article is to examine the role that memory and oblivion, forgiveness and unforgiveness play in Hannah Arendt's thought in relation to acts of violence in the political sphere. Political communities do not always decide to remember the crimes they have committed or the wrongs they have suffered, but neither can they always forget their mutual harms, even when there is already peace between them. Without striving to exhaust the entire subject matter of Arendt's work, I would like to show the difficulty in understanding the role of forgiveness in her thought and point out possible solutions when forgiveness becomes unachievable within the framework of her considerations. ${ }^{1}$

Historically, lasting peace agreements following war and upheaval have long been regarded as dependent on damnatio memoriae - i.e. the deliberate and mutual forgetting of violence and injustice. ${ }^{2}$ However, the effectiveness of the political amnesty clause is realistic only if certain principles have not been broken during the conduct of the war and that the parties involved in the conflict are more or less equal. The weakness of the idea of oblivion and amnesty became fully apparent after the end of World War I, when German society was left with the memory of unjust punishment, which was one of the reasons for World War II.

Arendt, herself a Jewish woman who had to flee from the Third Reich, analysed the phenomena of remembering and forgetting violence. In her approach, remembering and forgetting are an opportunity to establish within the political community the relations of its members with the past and future. Her consideration of the relation between violence and forgiveness can be divided into two stages. The first focuses on the idea of radical evil and the need to

${ }^{1}$ Arendt's thought about the conditions of the possibility of forgiveness of evil has been widely discussed. Jacques Derrida, Serena Parekh, Seyla Benhabib and Roger Berkowitz are probably the most famous authors who creatively developed Arendt's thought of evil and forgiveness. They tried to approach this topic ethically or legally. Such an approach is especially visible among authors who concentrated their work on a reflection on totalitarianism and the Holocaust and follow Arendt's thought that totalitarianism is the consequence of modernity. Authors such as Jeffrey C. Isaac, Roger Berkovitz and Elisabeth Young-Bruehl, have studied Arendt's thought to answer the question of roots of evil and reactions to it. However, there is also a difference between this kind of trend, where amnesty or reparation has moral or legal character, and my approach, more similar to Andrew Schaap, where reconciliation is conceived as a political activity that I develop more in the last part of my article.

${ }^{2}$ Forgive and forget, oblivio and amnestia, have for centuries been the main conditions for the transition from war or civil war to peace. Shortly after Caesar's murder, Cicero asked in a session of the Roman Senate in March 17, 44 B.C. that all memory of bad deeds should become eternally forgotten. The Peace of Westphalia (1648), which ended the Thirty Years' War in Europe, referred to the principle of eternal oblivion in introductory articles. Even today, the damnatio memoriae principle is still considered effective in establishing peace. Unfortunately, the enemies of the Roman Republic did not forget; they rejected the political system in the name of the empire and killed Cicero. In the case of the Peace of Westphalia, it ended the terrible catastrophe of the Thirty Years war, but the secret of its success was not the amnesty clause; rather, it was the invention of raison d'état and sovereignty (König, 2011: 45-46). 
forgive perpetrators for their crimes. Second, under the influence of the Adolf Eichmann trial, she developed the idea of the banality of evil, which points to situations so terrible that they transcend all human moral judgment, making forgiveness impossible.

In the first stage, the ability to remember the past is a promise of prolonged human access to what has already occurred in history and, thus, an increase in the scope of choices for the future. At the same time, remembering past evil often involves an increased feeling of the "burden" of the past hovering over the lives of victims and perpetrators. Such a burden of the past can sometimes only be rejected by cultivating the opposite of memory - the ability to forget about crime and violence. In some situations, therefore, oblivion ceases to be understood as guilty and becomes, as Friedrich Nietzsche believed, the ability to self-restrain (Nietzsche, 2006: 35-36). It becomes an opportunity to build a new political relationship both within and between communities. The paradox here is that forgetting is closely related to remembering because in order to forget, a community needs to know what can no longer be remembered. Thus, an appeal to forget appears as active work on memory, where forgetting is understood as forgiving past wrongs (Gordon, 2014: 496-498).

This way of "active" oblivion concerns both individuals and nations, as well as everyday life and the political sphere, and might be understood as attempts at finding a new political beginning after fundamental political conflict. In this situation, one can question whether remembering crimes helps or hinders the avoidance of further violence in terms of repairing relations between warring parties. If past mistakes are prematurely forgotten, there is a fear that they will be repeated in the future. This is the case, for example, with the Holocaust and Germany's responsibility for the atrocities of World War II. However, if people do not want to forget a terrible past - especially those living in Central and Eastern Europe - does this mean that they are particularly vindictive or that they are trying to protect themselves from repeating old mistakes?

Below, I will demonstrate Arendt's response to this problem by focusing primarily on three issues: (a) the role of forgiveness as a form of action that unlocks the future; (b) the role of changes in thinking about the essence of evil in Arendt's own deliberations and (c) the possibility of the inclusion of reconciliatory politics in her thought.

\section{THE ETHICS OF FORGIVENESS}

As with Aristotle, Arendt believes that man is primarily a zoon politikon. "All human activities are conditioned by the fact that men live together, but it is only action that cannot even be imagined outside the society of men" (Arendt, 1998: 22). 
Mancannotliveoutside of society; ifhecould, hewould have to be eitherabeastor a god (Aristotle, 1941: 1253a28-30). If we lived outside of society, we would not think and develop morally. For Arendt, thinking and acting are the most important human abilities, and are inseparable to dialogue (dia-logos) with others. They enable human beings to live a conscious and moral life in the social world. Thus, people are unable to live outside of the political community, although they cannot live with people who do not abide by the rules and who can hurt them or who have engaged in acts aimed at eliminating them from the community (Arendt, 1978: 188). Here, the problem appears to be what can be done when we are still required to interact with people who have wronged us?

In The buman condition, Arendt writes that forgiveness and action are closely connected to destruction and production. Human action is characterised by tragic irreversibility, and only forgiveness can be a remedy for "being unable to undo what one has done through one did not, and could not have known what he was" (Arendt, 1998: 237). Had we been unable to obtain forgiveness, our ability to act would have been limited to the first moment we did something wrong. Fortunately, because of the characteristics of human action, this does not hold true.

In this first phase of the development of Arendt's work, she characterises forgiveness as one of two essentially political ways of being. The second is our faculty to make and keep our promises: both faculties justify people's will to live together "because we exist primarily as acting and speaking beings" (Arendt, 1998: 181). In this way, forgiveness is the basis of our capability to sustain the existence of a political community. According to Arendt, when considering the large number of free but interdependent individuals, conflicts and rivalries are inevitable. However, she claims that efforts aimed at bringing private morality into the political sphere will either distort the free nature of political action or lead to political tyranny and violence. Thus, for the most part, politics and morality are not compatible. In other words, similar Immanuel Kant, she is sceptical of the idea of moralising politics. Nevertheless, when she analyses the role of the political sphere in The buman condition, she recognises forgiveness as a mechanism for healing violations in social relations. As she says,

Insofar as morality is more than the sum total of mores, of customs and standards of behavior solidified through tradition and valid on the ground of agreements, both of which change with time, it has, at least politically, no more to support itself than the good will to counter the enormous risks of action by readiness to forgive and to be forgiven, to make promises and to keep them (Arendt, 1998: 245). ${ }^{3}$

\footnotetext{
${ }^{3}$ Arendt perceives the concept of politics as completely contrary to violence. She writes, "Power and violence are opposites; where the one rules absolutely, the other is absent. Violence appears where power is in jeopardy [...] Violence can destroy power; it is utterly incapable of creating it" (Arendt, 1969: 56). For her, power is a political way of being together. Politics
} 
Arendt describes the act of forgiveness as an act that "withdraws" evil deeds and their consequences. In other words, forgiveness frees us from revenge and corrects past evil in such a way that its consequences are politically "abolished" and should no longer be taken into account in evaluating future actions. Forgiveness is, therefore, an act that sustains relationships in the community, destroying what was bad in the past and enabling the human world to continue, sometimes even renewing. It also has the power to releases the victim from the closed circle of revenge, which is the simplest reaction to harm.

At this point, it should be emphasised that Arendt does not imagine forgiveness as an act of historical amnesia, one in which the traumas of the past are concealed and completely ignored. Although she describes forgiveness as the opposite of revenge, she also calls it an alternative to punishment, not a replacement for it (Arendt, 1998: 240-241; MacLachlan, 2012: 57-58). Forgiveness and punishment have the same function: to end the spiral of violence. However, if forgiveness is substantially similar to punishment, the offender cannot avoid responsibility for the past - this would be contrary to the purpose of the punishment. Moreover, the reaction of oblivion would not be compatible with respect for a common history of political community. Thus, the "liberation" that, according to Arendt, engenders forgiveness is not a relief from the very fact of our actions, nor is it an exemption from our responsibility for them. Rather, the act of forgiveness prevents the past from fully determining the present (as in the case of the cycle of revenge and retaliation) and, thus, restores us to a state of relative freedom and to a new beginning (which, for Arendt, is a condition of politics itself). Therefore, forgiveness allows us to go beyond the identities of the "victim" and "perpetrator" created by the original unlawful act.

Although forgiveness does not mean that the wrongful act is erased from public memory, it changes the way in which people can approach the wrong.

takes into account public space, namely the space where politics is played out. In this way, it refers to the space "where I appear to others as others appear to me, where men exist not merely like other living or inanimate things but make their appearance explicitly" (Arendt, 1998: 199). Political space is, above all else, a sphere in which people appear to each other in such a way that each person appears to the other as a separate individual being. As she writes in The buman condition: "The space of appearance comes into being wherever men are together in the manner of speech and action, and therefore predates and precedes all formal constitution of the public realm and the various forms of government, that is, the various forms in which the public realm can be organized" (Arendt, 1998: 199). Violence tears this space apart. Violence destroys power because it is unreflexive and reactive and, thus, destroys our potential to develop ourselves. Ultimately, violence sinks into the reluctance, rage, hatred and affective states enslaved by the past. People, unable to break from the trap of wounds from the past, seek revenge without thinking and judging the situation. Thus, our ability to act and engage in action on which freedom depends requires abandoning the desire for violence so that we can renew our commitment (Mrovlje, 2016). 
In the same way an apology made by the perpetrator can change the original meaning of the crime in the eyes of the victim, forgiveness by the victim can change the relationship between a victim and perpetrator. Arendt's willingness to forgive therefore allows people living in harmed societies to re-enter the sphere of political debate with former enemies and, by rejecting vengeance and violence, to return the perpetrator to the common political sphere. However, it does not mean the end of politics or perfect reconciliation; as with all political activities in Arendt's work, it represents a new beginning. Thus, what Arendt (Arendt, 1998: 246; Grey, 2019: 51-52) calls an act of forgiveness is a renewal of the trust needed to provide the political space to re-establish relationships in a more harmonious way between members of the community or among communities. This renewal of trust is based on people's continued and sustained commitment to the political community as well as on respect for co-fellows. The result is based on a desire to trust others enough in order to enter the space of political activity. If the above reconstruction is accurate, then acts of political forgiveness can be understood in the light of Arendt's theory in such a way that they free us enough to move forward together. Evil becomes locked in the past so as not to determine the future.

This is how Arendt solves the problem of irreversibility regarding human deeds. By forgiving perpetrators, victims can liberate themselves from the limitations of the inevitable consequences of the evil actions of wrongdoers. When our faults are forgiven, we can move forward. Not being angels, we are prone to making mistakes. These everyday phenomena result from the very nature of individual actions and constantly enter into new relationships within the network of social relationships. Mistakes also require forgiveness in order to extricate people from unconscious behaviour. It is only through this constant mutual liberation from what has been done can people remain free from the past. Moreover, it is only under the condition of readiness for change that people have a real chance of starting over. Thus, we can say that, for Arendt, forgiveness mitigates the irreversibility of the past. ${ }^{4}$

The problem with Arendt's approach is that the power of forgiveness lies precisely in its unpredictability. Forgiveness is unpredictable because it "is the only reaction which does not merely re-act, but acts anew and unexpectedly unconditioned by the act which provoked it and therefore freeing from its consequences both the one who forgives and the one who is forgiven" (Arendt, 1998: 241). Nevertheless, if forgiveness is an effective way of acting, to the

${ }^{4}$ Arendt goes so far as to say that forgiving "serves to undo the deeds of the past" (Arendt, 1998: 237). In a way, this claim is false. Reversing what has been done is exactly what forgiveness cannot do. A crime cannot be removed from the field of social facts. Forgiveness itself presupposes an offense. Every time forgiveness is offered, the crime invoked is remembered. Without the offence, there would be nothing to forgive, so forgiveness cannot eliminate the offense (La Caze, 2006: 273-293). 
point that it is unpredictable (a new beginning), like all beginnings, it can take a violent form. ${ }^{5}$ Therefore, the unpredictability of the action must be mitigated by the second mode of action, which, according to Arendt, is the promise.

In The buman condition, Arendt introduces a promise as a remedy for the irreversibility and unpredictability of processes initiated by human action. The ability to make and keep promises responds to the weakness of human affairs (Arendt, 1998: 237). Promises serve to establish a sense of security that ensures the continuity and permanence of interpersonal relationships towards an uncertain future. The promise stabilises relations in the political community and protects them from the unpredictable consequences of human action, mainly because it is a mechanism that controls the future (Arendt, 1998: 244-245). As such, a promise is a commitment, as well as a guarantee, that binds people together and allows them to act in harmony towards fulfilling it. According to Arendt, the ability to make promises has the power to bring communities closer to their own beginnings, i.e. to restore their memory to the point where they agree on the purpose of the action. In this sense, the promise is a reminder that there is still something important that connects individuals within the group with the past (from which these individuals originate and in which everything began). Therefore, for Arendt, the promise controls the future. In doing so, it reverses the flow of time and "tames" the uncertain future by rooting it from the past. In this sense, to Arendt, each promise is not just a form of memory directed at the past; it is also a form of oblivion directed towards the future. ${ }^{6}$ However, her later experiences, above all else, her participation in the Eichmann trial, changed her views on the issue of the possibility of forgetting and forgiving crimes. From that moment, instead of the ethics of forgiveness, Arendt starts to build an approach that we can name the philosophy of the

${ }^{5}$ In the book On revolutions, Arendt declares that beginnings are always turbulent because they are often associated with violent riots that violate the status quo. However, if a beginning is related to violence (war, revolution, etc.), then political power, which is supposed to be the opposite of violence, is exposed as emerging from the original violent source. To illustrate this, Arendt refers to some of the most famous political beginnings which, in her opinion, "confirm" the inseparable link between violence and beginning, such as the killing of Abel by Cain. However, accepting that violence and power are opposed leads to a problem in her theory because, according to her, nothing can be initiated without violence; at the same time, the origins of power are seen as diametrically opposed to violence. Authority is the result of an act of violence, but violence is also what destroys authority (Maze, 2018: 133-134).

${ }^{6}$ It seems that Arendt's understanding of the promise in terms of commitment to the past contradicts her understanding of freedom as the ability to start over (Arendt, 1998: 237-244). She argues that every beginning is starting over and, therefore, requires a return to the past. It is not known, however, how a return to the past can generate a new beginning, in other words, how the past can renew itself. From a memory perspective, it seems that the beginning is never really new and that it is always the return to the past that is remembered. The question then arises as to how Arendt imagines the transition from remembering, understood as sticking to the past, to action, understood as spontaneous freedom to shape the future. 
unforgivable, which posits that past crimes should be remembered. Therefore, the experiences of the 20th century inclined her towards the view that there are crimes that cannot be forgiven.

\section{THE UNFORGIVABLE OF THE BANALITY OF EVIL}

For what situations, then, can we not forget or render just punishment? According to Arendt, the unforgivable relates to Nazi crimes, a new type of crime - a planned administrative massacre. Due to the unprecedented nature and extreme cruelty of the crimes committed by the Nazis, the inadequacy of the existing judgments appears to circumvent the imposition of just penalty (Perrone-Moisés, 2006).

According to Arendt, there are three main reasons why forgiveness in certain political situations is impossible. The first reason is related to a change in Arendt's understanding of the phenomenon of evil, under the influence of the Eichmann's trial. ${ }^{7}$ In Eichmann in Jerusalem, the key to understanding the source of bad deeds is no longer Kant's concept of radical evil but instead the banality of evil. Eichmann - who was one of the organizers of the Holocaust - represents in the book the banality of evil, because "he merely, to put the matter colloquially, never realised what he was doing" (Arendt, 1964: 284). He was an ordinary bureaucrat who didn't have even the intention to perform evil deeds. Second, Eichmann was not a monster. He was a clown who did not use his power of judgment. Moreover, the criminal of his sort is not a moral person at all because he was unable to think from the standpoint of somebody else. Following the example of Socrates, Arendt claims that man becomes a reasonable and moral human being in the process of independent thinking and remains such a person until he or she retains the ability to sustain such a reflexive way of being. Thus, as it turns out, contrary to Arendt's earlier analysis, some situations and acts cannot possibly be forgiven. We cannot forgive Eichmann, even if we want to, because he stops being a subject in the moral sense. ${ }^{8}$ The third reason concerns collective responsibility. All ways of talking

${ }^{7}$ In Eichmann in Jerusalem, Arendt suggests that our ability to establish new relationships with criminals is partly due to our ability to see ourselves in them. "The reflection that you yourself might have done wrong under the same circumstances may kindle a spirit of forgiveness" (Arendt, 1964: 298). This reflection often requires understanding that even if the action was bad, it was not due to bad reasons. In the rare cases that we are forced to conclude that the action was intended as evil, forgiveness seems pointless. If forgiveness consists in creating opportunities for a new future in which conditions are not determined by past offenses, and those who commit evil are unable to act in a new and better way, then forgiveness in such cases simply does not serve its purpose.

${ }^{8}$ To clarify possible misunderstandings, it should be added that the banality of evil does not mean for Arendt diminishing Eichmann's role in the Holocaust or morally diminishing 
about collective guilt are based on abstract assumptions and are an escape from the sphere of determinable facts and individual responsibility (Arendt, 1964).

The concepts of guilt and innocence make sense only in relation to individuals. Moreover, the concepts of guilt and collective responsibility are used by individuals who feel real responsibility for their community; those who really should apologise often hide behind their backs. In situations where everyone is guilty, the notions of guilt and responsibility become meaningless. Therefore, it is quite obvious that in Arendt's late works, she was inclined to the viewpoint that all ideas of forgiveness in politics - when an act was knowingly committed by perpetrators in a way that defies the possibilities of human moral judgment - are either short-sighted or simply result from an absence of thought.

According to Arendt, reconciliation and forgiveness are no longer possible from this new perspective because banal evil cannot be forgiven. Earlier, Arendt claimed that "men are unable to forgive what they cannot punish and they are unable to punish what has turned out to be unforgivable" (Arendt, 1998: 241). Now, although "banal" evil is an extreme evil and cannot be forgiven, it must be punished, even when the punishment is inadequate in relation to the nature of the crime (La Caze, 2014:213). Thus, wrongdoing is not a reason to give up thinking or politics because people retain the ability to start over. Therefore, even in Arendt's new approach to evil, there is still a possibility to create within a community or among communities a just relationship after traumatic experiences of past violence. At this point, we can seek conditions that would allow victims to co-exist with perpetrators after crimes such as genocide or ethnic cleansing. ${ }^{9}$

Given the considerations from Eichmann in Jerusalem, it seems that Arendt no longer sees this possibility of justice in ethics but in the law. It is the law that becomes the only chance for her to restore a substitute for justice for victims.

his deeds. In her analysis she only pointed to the horrifying "normality" of this man. Arendt turned public attention to the "banality" of evil, and to the fact that people like Eichmann, do not have to be a "beast", as Ben Gurion wanted to show during his trial in Israel, to make a new mythological legitimacy of the state and politico-educational spectacle. Because of that her name was dragged by many through muck and mire.

${ }^{9}$ It is worth referring here historically to the process of shaping German memory after the Second World War. In Germany right after the war it was a time without history, teaching in schools was focused on the present, government and people want to forget about the past. The basic idea was to show that the Nazis were responsible for war crimes. However, there was a breakthrough in the 1960s. The young generation questioned the previous narration of their fathers. From that moment, it was increasingly recognized that not only the Nazis, but the German army participated in the war crimes, not only selected people from the authorities, but the whole society knew about the concentration camps etc. Thanks to these slow changes in memory and thanks to discussions about guilt and responsibility within German society (a famous one was Historikerstreit in the 1980s), in the 21 st century it was possible to commemorate Holocaust victims in Berlin. In effect, the Jewish Museum Berlin (2001) and the Memorial to the Murdered Jews of Europe (2005) were built in Germany. 
Despite the fact that the trials of Nazi criminals left much to be desired because a substantial number of criminals remained at large after the war, she still sees the possibility of compensation for harm and injustice in the legal punishment. Although forgiveness of such harm is a matter of the individual conscience of each of the victims, only in a legal system is it possible, even partially, to judge specific individuals for certain acts so that the community as a whole can move forward. It was thanks to the Nuremberg trials that it was possible to prove the guilt of at least some criminals (Wigura, 2008: 130-136). ${ }^{10}$

\section{THE POLITICS OF RECONCILIATION}

However, within Arendt's considerations, there might be a mechanism that was neither the moral plane of individual forgiveness of victims nor the legal sphere of justice. There are crimes that cannot be adequately settled, even in court. In other words, when examining the numerous gestures of reconciliation after World War II, one should consider whether they can be validated on the basis of Arendt's assumptions. If this were impossible, then Arendt's theory itself would be in trouble - it would close the possibility of opening political action to the future, action to a new beginning. Therefore, apart from the legal realisation of justice, there is also another, neglected possibility that should be taken into account in the context of Arendt's deliberations, namely the idea of political reconciliation and pardon. Regardless of the issue of remembering or forgetting past criminal acts or of victims' inability to forgive perpetrators, when the nation has been so badly wounded that it is unable to reach justice through ordinary procedures, it needs extra coordinative methods to allow its members to re-create the community. Then, as in the case of the truth and reconciliation commissions in Chile and South Africa, there is a need to rethink the idea of political reconciliation.

In her work, Arendt provides some clues as to how this reconciliation might work and the kinds of conditions the community would need to achieve it. Generally, for Arendt, political reconciliation is a mechanism based on respect for other human beings. She understands respect as a form of political

${ }^{10}$ From the perspective of Arendt's ethical considerations, one more mechanism can be recalled here. It is the idea of extended reasoning, which aims to sensitise people to evil by recalling past crimes; it is to help us recognise dangerous situations to prevent the recurrence of violence. For Arendt, practically all her work, from The origins of totalitarianism to the lectures on Kant, is a way of understanding how phenomena such as Nazism and fascism, which undermined all previous standards of moral evaluation of events, could have happened. In this situation, in her opinion, one way out of a world without moral standards is to resort to the imagination and sensus communis. It allows us to look at things from the right perspective and judge them without using pre-defined rules. For Arendt, this also allows us how to create the distance necessary for impartial judgment. In this way, we have the opportunity to reconcile, even in the face of a tragic reality. 
friendship without intimacy. However, this mechanism can be applied only to extreme evils or wrongs that have been done by mistake. In such situations, there can be political forgiveness for the sake of a person (Arendt, 1998: 241242). Moreover, because of her reflection on collective responsibility, there cannot be political forgiveness of a group. Thus, from Arendt's perspective, only political apologies or amnesty for a particular crime is acceptable.

Especially the practice of political apologies is seen in many processes of reconciliatory justice - such as in the Rwanda Gacaca trials - in which forgiveness is understood as primarily individual in nature.

When we look at existing mechanisms of reconciliation occurring in the form of commissions, we see that reconciliations, political pardons and amnesty can be understood as mutual forgetfulness, while ethical forgiveness, through its long tradition, evokes the past to such an extent that it makes it present again - remembering the harm so that it can be truly forgiven. In contrast, the goal of reconciliation often creates conditions for instrumental amnesia so that a community in which perpetrators and victims are mixed in an impossible way might continue to function through separation (e.g. in South Africa). ${ }^{11}$ Thus, reconciliation committees, by giving a voice to victims, are an attempt (though not always possible and successful) to "heal" the wounds that divide a given society and create conditions under which it could cross over from the past as if nothing happened. Reconciliation, depending on the situation, can either refer to the idea of forgiveness, which requires the exact recall of wrongs to be forgiven, or the idea of amnesty, which tries to cover the psychosocial traces of earlier crimes. Both of these ways - forgiveness and amnesty - are modifications of collective memory. Forgiveness reminds us of harm, "opening" a wound so that all harms can be truly forgiven. In contrast, amnesty can be understood as recognition that past deeds will not determine actions between the parties in the future (Krapp, 2005: 190-194). Furthermore, although the work of reconciliation commissions does not exclude the possibility of individual forgiveness for perpetrators, it is more often seen that their action coincides with the idea of amnesty because they are a political tool of normalisation and continuity. ${ }^{12}$

${ }^{11}$ One should also remember about the difficulties of seeking correction of the past crimes through reconciliation process. For example, in Chile experts criticized the commission's mandate, which was limited in that it was only allowed to investigate crimes resulting in death (Ensalaco, 1994). In Rwanda, although the government has created many programs to build the feeling of "one nation", ethnic prejudices, mistrust, and discrimination among Hutu and Tutsi has been still continued. Nevertheless, my perspective is not focused on whether and to what extent the reconciliation is empirically successful. I develop theoretical argument that show that based on Arendt reasoning we can justify possibility of political reconciliation beyond legal issues or practical thinking that seems available only to a few.

${ }^{12}$ In the case of amnesty, the purpose of appealing to it mainly means that hostilities and acts of violence are to be actively forgotten and should no longer take place in public communication. For the amnesty clause to be successful, war crimes must be rare. If they 
Therefore, the real task of a reconciliation is not to promote national forgiveness, or reduce a sense of revenge, but to enable those affected to participate in the daily life of their political community (Teles, 2006). As such, in situations where democratic communities do not have the necessary strength and conditions to find a just solution in the event of human rights violations, they often reach out to the commission of truth and reconciliation to ensure that the community returns to normality. ${ }^{13}$

Referring to Arendt's theory and her idea of promise, we can better understand why the lack of forgiveness undermines politics. It happens because politics is a sphere in which we shape our moral ideas together with others. True and honest apologies, including the promise to not allow the recurrence of wrongs, are essential to political life (La Caze, 2014: 220). Moreover, citizens always have a chance to create better political relations because they participate in a political sphere that is understood as embodying pluralistic and agonistic activities. On one hand, this means that they will not always agree on the assessment of the past, and thus, the result of reconciliation cannot be predicted in advance. On the other hand, there is no determinism that the past would block the possibility of future political change.

Following Arendt's non-instrumental and communicative approach to understanding politics, political reconciliation might be understood as a goal towards which victims can orientate rather than as an inevitable result of their actions. In this way, citizens can understand themselves as living in conditions enabling reconciliation and not as those seeking reconciliation. Based on Arendt's deliberations, the policy of reconciliation can, therefore, be imagined as a democratic deliberation that takes place in the political sphere, constituted by the promise of a new beginning. Deliberation and continuity are maintained by the willingness of victims to forgive the perpetrators of their wrongs, wrongs for which they truly apologise and accept punishment and in so far as both parties are still willing to co-create a political community. ${ }^{14}$ This, of

dominate the war arena and exceed a certain limit, the demand for oblivion becomes unrealistic. Crimes against ius in bello can only be forgotten if the boundaries have not all been crossed. At the same time, amnesty does not mean that the act was not bad, nor is it a pretext or a way to remove legal grounds. In fact, the amnesty only states that despite this particular act, no legal proceedings or expected consequences will occur. At the same time, amnesty as a political instrument must be legislatively limited in order to avoid abuse. It must also remain an exception. In other words, there must be cases that do not qualify for amnesty, such as torture and genocide, war crimes and crimes against humanity (König, 2011: 48).

${ }^{13}$ In general, the effects of the pardon granted by the amnesty laws are limited because forgiveness is the privilege of victims, not the majority of members of the society concerned or their political or judicial representatives. Because these crimes are targeted at victims in their human condition, it can be said that pardon is the privilege of humanity (Teles, 2006).

${ }^{14}$ My approach refers to a perspective closer to Apel or Habermas, not to the perspective that Shaap presents in his reflections on Arendt's thought and reconciliation. His approach is 
course, does not mean that such an attempt at reconciliation will allow us to fairly settle the past or forget it. Separating the past from a new beginning does not have to lead to the reconstruction of social harmony. Such a mechanism, however, provides an opportunity to be part of the society, to be free from extreme situations, from the consequences of the actions of perpetrators and to start building the community anew.

\section{BIBLIOGRAPHY}

Aristotle. (1941). Politics. The basic works of Aristotle. (B. Jowett, Trans.). (R. McKeon, Ed). New York: Random House.

Arendt, H. (1964). Eichmann in Jerusalem. The report of the banality of evil. New York: The Viking Press.

Arendt, H. (1969). A special supplement: Reflections on violence. New York: The New York Times Review of Books.

Arendt, H. (1978). The life of mind. Orlando: Harcourt Books.

Arendt, H. (1998). The buman condition ( $2^{\text {nd }}$ ed.). Chicago: Chicago University Press.

Benhabib, S. (Ed). (2010). Politics in Dark Times. Encounters with Hannab Arendt. Cambridge: Cambridge University Press.

Berkowitz, R. (2011). Bearing logs on our shoulders: reconciliation, non-reconciliation, and the building of a common world. Theory \& Event, 14(1). Retrieved from: http://muse.jhu. edu (12.02.2020).

Derrida, J. (2001). On cosmopolitanism and forgiveness. New York: Routledge.

Ensalaco, M. (1994). Truth commissions for Chile and El Salvador: A report and assessment. Human Rights Quarterly, 16(4), 656-675.

Gordon, M. (2014). Between remembering and forgetting. Studies in Pbilosophy and Education, 33(6), 489-503.

Grey, S. (2019). Returning to the source. Theoria, 66(161), 37-65.

Isaac, J.C. (1993). Situating Hannah Arendt on action and politics. Political Theory, 21(3), 534-540.

Jackson, M. (2002). The politics of storytelling: violence, transgression and intersubjectivity. Copenhagen: Museum Tusculanum Press.

König, H. (2011). Paradoxien der Erinnerung über Wissen und Vergessen. Osteuropa, 4, 43-54.

Krapp, P. (2005). Amnesty: between an ethics of forgiveness and a politics of forgetting. German Law Journal, 6(1), 185-195.

La Caze, M. (2006). Should radical evil be forgiven? (pp. 237-293). In: T. Mason (Ed.). Forensic psychiatry: Influences of evil. Totova: Human Press Inc.

La Caze, M. (2014). Promising and forgiveness (pp. 209-222). In: P. Hayden (Ed.). Hannab Arendt. Key concepts. New York: Routledge.

Leebaw, B. (2011). Judging state-sponsored violence, imagining political change. Cambridge: Cambridge University Press.

MacLachlan, A. (2012). The philosophical controversy over political forgiveness (pp. 37-64). In: B. van Stokkom \& P. van Tongeren (Eds.). Public forgiveness in post-conflict context. Cambridge: Intersentia Press.

appreciating more agonism as a tool of critique that can serve to evaluate political processes in practice (Schaap, 2005). 
Maze, J. (2018). Towards an analytic of violence: Foucault, Arendt \& power. Foucaultian Studies, 25, 120-145.

Mrovlje, M. (2016). Forgiveness, representative judgement and love of the world: Exploring the political significance of forgiveness in the context of transitional justice and reconciliation debates. Philosopbia, 44(4), 1079-1098.

Nietzsche, F. (2006). On the genealogy of morality. (C. Diethe, Trans.). In: K. Ansell-Pearson (Ed.). Cambridge: Cambridge University Press.

Parekh, S. (2004). A meaningful place in the world: Hannah Arendt on the nature of human rights. Journal of Human Rights, 3(1), 41-53.

Perrone-Moises, C. (2006). Forgiveness and crimes against humanity: A dialogue between Hannah Arendt and Jacques Derida. Zeitschrift für politisches Denken, 2(1). Retrieved from: www.HannahArendt.net (07.02.2020).

Schaap, A. (2005). Political reconciliation. London: Routledge.

Teles, E.L. de A. (2006). Amnesties, pardons, and national reconciliations. Zeitschrift für politisches Denken, 2(1). Retrieved from: www.HannahArendt.net (16.02.2020).

Torpey, J. (2001). "Making whole what has been smashed": reflections on reparations. The Journal of Modern History, 73(2), 333-358.

Wigura, K. (2008). Hannah Arendt o przebaczeniu i polityczności. Znak, 640, 130-136.

Young-Bruehl, E. (2006). Why Arendt matters. New Haven: Yale University Press. 